\title{
Drama Club: A Creative, Performing, Multidisciplinary and Cultural Laboratory in Tirana University
}

\author{
Erenestina Gjergji Halili", Eljon Doçe \\ Department of Literature, History and Philology Faculty, University of Tirana, Albania
}

Received June 11, 2020; Revised July 24, 2020; Accepted August 25, 2020

\section{Cite This Paper in the following Citation Styles}

(a): [1] Erenestina Gjergji Halili, Eljon Doçe, "Drama Club: A Creative, Performing, Multidisciplinary and Cultural Laboratory in Tirana University," Universal Journal of Educational Research, Vol. 8, No. 10, pp. 4498-4506, 2020. DOI: 10.13189/ujer.2020.081017.

(b): Erenestina Gjergji Halili, Eljon Doçe (2020). Drama Club: A Creative, Performing, Multidisciplinary and Cultural Laboratory in Tirana University. Universal Journal of Educational Research, 8(10), 4498-4506. DOI: 10.13189/ujer.2020.081017.

Copyright $\bigcirc 2020$ by authors, all rights reserved. Authors agree that this article remains permanently open access under the terms of the Creative Commons Attribution License 4.0 International License

\begin{abstract}
The school theatre is, above all, a dramatic laboratoric experience of the texts, which usually comes into contact through reading. The dramatic laboratory is seen as a potential method for updating the creative expression of the students, for their decoding ability of the dramatic, classic and modern texts but also is seen as an effective pedagogical and didactical strategy and methodology, which has turned out to be very successful. As it will be mentioned in this paper, the process of dramatization, accompanied with the method of the reading (the table process), the reflection and the consciousness has stimulated other qualitative processes of the mastery of the material, such as language as a symbol; the theatrical play as a performance and as body language; the interaction and the communication through the respect of the ethnic and cultural diversities. The technological developments, which was applied from us into Desktop Theatre is a methodology of the virtual presentation and has increased the interest and the attention of the public, which comes from the university sphere and a broad type of public. It is worth emphasizing that "The Drama Club" is a unique type of club in the whole Albanian university system, and it also has an international recognition and was the first club that has brought for the first time into focus learning through theatre as well as the presentation of the dramatic works, which are staged for the first time by this club.
\end{abstract}

Keywords Theatre in Education, Dramatic Text, Dramatization, Theatrical Multimedia, Education, Socialization

\section{Introduction}

This paper aims to put forward the perspective that the learning process and the consolidation of knowlege through theatre in the pre-universitary and universitary system is now a theoretical and a practical reality in almost all the educational systems around the world, which has been in practice since 2013 and is also a reality at the University of Tirana.

Confucius used to say: "If I listen, I forget, if I see, I undersatnd, If I do, I learn"!

Learning and knowledge consolidation through theater in pre-university and university systems is now a theoretical and practical reality in education systems almost in all around the world.

Theater, considered as a great value-forming element, also relies on the experiences of the dramatic textbook laboratory, which usually comes into contact only through reading; here we are referring to textbooks of old and postmodern literature, which show various difficulties in analyzing, recognition and reception.

However, theater is the technique through which you are taught to work in groups to discover and manage the capacity of pupils, students and their resources through voice, gestures, mimicry, body language, and textual interpretation. This creates valuable and necessary spaces in the consolidation of the individual-group relationship, 
the increase of cooperation through recognition, as well as the interdisciplinarity as a necessity of curricular interaction.

\section{Methodology}

This paper uses the methodology of proces drama, something Gavin Bolton and Dorothy Heathcote have theorized as a teaching methodology, as part of pedogogy and didactics, as the goal of the laboratory of the "The Drama Club", and also the fulfilling of the scientific research over the old dramatic texts. These texts are in contact only by reading them and implying texts of old and the postmodern literature which represents different difficulties in the literary reception.

The methodology of our research in this paper is qualitative. It is grounded mainly in the descriptive approach of the pedagogical process of working with students of the Drama Club, specifically as it deals with the organizational, structural and technical elements.

Thus, part of the methodology is the well detailed analysis of the process of the adaption and the emotional transformations that students have shown, starting from their induction into the club to their performance in the scene. This element is specificially important to understand the effect that the scenic performance brings to the conscience mind and to the whole existence of students to perpare them for challenges that start in the scene, but that don't finish there.

This analysis continues with the evolution of the structure of the Club through years (the growth of the Club and the profilization of the students in different and specific processes in their attempt to build a team). From the study point of view "Drama Club" can be considered as a focus group which is a perfect case study of how the processes of the internalization of the scenic-dramatic experience are not merely academic and professional fields, but are also didactic through which students learn a great number of cognitive, social, philosophical, spiritual and human processes.

\section{Argumentation}

As far as we know, the term "drama" implies all forms of use of theatrical means, not only in aesthetic and artistic functions, but also for educational purposes. It is a very important part of the curriculum, which includes aspects of material, spiritual, artistic, intellectual and emotional culture, where society and culture interact.

"Drama education is a powerful teaching and learning tool with profound positive effects on a student's cognitive, social, emotional, and physical development. The benefits of regular theatre arts instruction spills over into all school subjects and everyday life" (Clark. R., 2013:1).

Drama-dramatization is important, because as it is universally accepted, it not only influences the recognition and deconstruction of literary texts, specifically typological definitions, diachronic and synchronic developments of the text itself, but also the formation of personality of pupils and students. On the other hand, it gives them a broader cultural formation. Gender itself, through the dramatizing process, produces and finalizes an aesthetic, artistic and spectacular product through artistic performances, theater, and final organizational discipline.

"The drama is what the writer writes; the script is the interior map of a particular production; the theater is a specific set of gestures performed by the performers in any given performance; the performance is the whole event, including audience and performers (technicians, too, anyone who is there" (R. SCHECHNER, R., 1994: 87).

Knowing the aesthetic and artistic aspects of the theater, as well as the critical and analytical evaluation of foreign and Albanian literary texts, through speech, play-reading has created the possibility of touching the elements and principles of stage art by giving students the opportunity to become familiar with the scenic elements, scenography, costume design, semiotics, and theatrical spaces, but also the types of theater and their application. Following this process, the students themselves receive all the stage experience, going through a concrete realization process.

It should be noted that multidimensional experience increases communicative intensification through emotional and social cooperation. Even through the decomposition of character dimensions, which they select, relying on the semiotic communities provided by the text itself, they transform them into lexemes, metaphors, contextual, or real paradigms." A text is a structured and unified story, comical or tragic, complete, with a start and a central part, and an end that expreses the passion and the vision of life of the play writer, which depicts the conflicts that occur and that lead to a culmination (the point of the solving of the conflict) and that deals with stronger dimensional characters, and also the needs and goals that can motivate their personal actions" (Louis, E. Catron.,1993)

A very interesting fact is the observation of the character as a subject, the discourse, or the psyche of the character in a discourse situation, etc., elements which are concretely decomposed in the drama laboratory and become tangible for the students.

Theatrical experience also stimulates different forms of learning, strengthening and directing creative energies and at the same time consolidating aesthetic principles and artistic tastes. As a basis for the theatrical performances, several working methods are known, which constitute the union of the two directives. Words plus animation remains a pedagogical proposal and a proposition of theatrical art, as didactics. "By going from literature into the spectacle, we pass from conceptual and imaginative perception, into a more sensible perception. But this border is rigid. For instance, a fictional text which is verbally communicated contains elements of the sensorial interpretation (the voice of the narrator, the articulation, the tone, the diction), 
without ever being a spectacle." (T. Kowzan., 1975: 182)

Studies have shown that developing the ability to interpret is found in the nature of theatrical interpretation. Dramatization is a special form of learning. The programs compiled for the pre-university cycle have given students the opportunity to get acquainted with the dramatic text, by requesting the development of theatrical performances. The dramatic text during a lesson is the cause of a more massive activation of students, who in most cases, express the desire to play the role of a certain person in a drama.

"The written text, in other words, is determined by its need for stage contextualization, and indicates throughout its allegiance to the physical conditions of performance, above all to the actor's body and its ability to materialize discourse within the space of the stage (ELAN, K., 1980: 208-9).

Dramatization as a creative process, which is one of the forms of trans modeling of the text, leads to the essential change of the communication scheme with the recipient. It fundamentally changes the relationship between dialogue and narrative (Hasani, D., 2015). This is an issue that lies between drama and theater on the one hand, and drama literature in general on the other.

"School" and "Theater" binomials represent an educational opportunity of very high pedagogical value. The theater which is developed from an early age helps students:

- To understand and appreciate oneself, others and the environment through dramatic imaginative experience.

- To communicate ideas and feelings through language, expression, and movement in real and imaginary contexts.

- To develop self-confidence and self-esteem in daily interactions with others.

- To develop sensitivity to the feelings, opinions and values of others through intentional interaction; to develop a wide range of dramatic skills and techniques" (Karamitri, E; Koçi, P; Murthi, M; Pepa, V; 2001: 59).

"Drama extends and builds subjects on this natural process" (Karamitri, E; Koçi, P; Murthi, M; Pepa,V; 2001: 59). This is one of the reasons why children and adults like it. "Through theater and its valuable instruments, children are able to take the right path towards self-discovery, and this is in favor of controlling their emotions in the right way, by making them more aware; it also encourages the discovery of a great force within them to cope with difficult situations and contrasting feelings "(http: //www.scuola.net/storia-antica/storia-del-teatro.html).

\section{Theater and Other Activities}

The theater is closely related to everyday life with different types of activities and at the same time with many components of education. This is a bilateral connection, because it not only takes into account many of these components, but also contributes to their realization. As E. B. Landon states "among the thorniest of issues that teacher educators deal with is the relationship between theory and practice." (Landon E. B., 2001:1)

By exploring such topics as: "National identity; knowledge of cultures; human rights; peaceful coexistence; the student contributes through theatrical activities by revealing the values of his own culture, respecting and promoting the values of other cultures, by cooperating alone and in groups in various activities by giving his own contribution, providing solutions to a variety of theatrical / artistic issues by using accurate theatrical language to communicate values and attitudes, by explaining different techniques and stage processes related to other areas they learn" (http: //www.scuola.net/storia -antica / story-del-teatro.html).

\section{University Theater - Drama Club}

The Drama Club was established for four years (2012), at the Department of Literature, Faculty of History and Philology, UT, an innovation-based organization for the needs of the didactic and pedagogical laboratory in the Drama curriculum, which had also been missing for years as a separate curriculum, and the third studied gender of literature, in all the study cycles. In the first year, we dismantled texts of world drama, its classics, as well as Albanian classics. We had Shakespeare, Goethe, Schiller, Kamy, Sartr, Jonesko and Anton Santorin, Fishta, S. Frashëri, (we are talking about Albanian authors), who came to the original writing of their texts. Our theater also became a very effective means of communication that was able to fulfill a "social function", as it taught them to overcome the "fear" of public speaking. This objective was successfully realized in our Club.

"The power of drama in teaching literacy lies in its ability to bring about emotional interactions with characters from literature in the fictional world of drama." (Booth, 2000; Wilhelm \& Edmiston, 1998, cited. Heyward, P., 2010: 198)

The teaching of theater in the Drama Club, proved effective, as it was entirely based on the possibility of emotional involvement of the individual with the dramatic literary text or not, in the acquaintances, practice and correct pronunciation of vowels and consonants, word diction, correct pronunciation of it, the technique of logical, rhythmic and emotional emphasis, as well as the role of intonation in communication.

With the dramatization of the text, it promoted the teaching of a technique, which emphasizes the character, the presence of the mind, the ability to act and move, the creative intuition, art and music, but also the ability to meet a text through dramatic action. All in all, it showed a new 
way of understanding and learning. It was extremely important for us to understand that theater in our institution is something else that is subject to professional rules, i. e professional theater. Theater in school cannot be theater, but "Theater education" and this absolutely requires pedagogical training in the transmission of schooling skills as the rules are set, which are learned and mastered during the specific expertise of the respective faculty. As P. Bundy states in the audience, students are exposed to a live performance, and to their teachers taking a risk - which is often positively perceived by students (Bundy et al. 2013).

Educational objectives in this field were clearly approached with communication at the dynamic-relational level, infused with interpersonal communication between psychological, social, cultural, emotional actors.

- Students regained their identity, developed awareness of their role in the group, regained cognizance of the emotional dimension, (for certain individuals it is an essential prerogative), for the development of consciousness and for the value of the person and solidarity. At the Drama Club, students with physiological speech problems were socialized, who managed to overcome them quite well and perform like their colleagues.

- We noticed that stimulation, through theater, also appears as perfection, as an attitude against individualism and existential loneliness. Also, education through theater associates autonomy, to promote individual choices in a healthy space of democratic coexistence. The deconstruction of foreign texts by modern and postmodern authors mainly served this purpose.

- Such training, through the creative theater laboratory, gave immediate results in function of the innovation of educational and didactic practice.

- This educational project was characterized as a contract of "education" with students in the process of evolutionary development.

"Teachers and students (leadership and people), as well as content on reality, are both subjects which not only help in the task of unveiling that reality, and thereby coming to know it critically, but also interact in the task of re-creating that knowledge. As they attain this knowledge of reality through common reflection and action, they discover themselves as its permanent re-creators"

(Freire, P., 1968: 69).

\section{Theater, A Training Tool}

As a new pedagogical and didactic model, it tends to develop an interactive series of skills and abilities needed for a real student and pupil education, especially including tools and technologies, visual and multimedia, that are more appropriate for the communicative situation of the pupil or student.
"While the emotional potential of drama is well established, Courtney (1988) provides insight into how emotional engagement in drama is also a safe experience for learners." (Heyward, P., 2010: 198)

Theater is presented as an interactive form of different languages: verbal, nonverbal, imitative, gestural, prosodic, portrait, musical, etc ... In the "multimedia" language, it has emerged as a valuable tool of training, multidisciplinary and interdisciplinary, valuable as a mean of symbolic-semiotic, emotional, dynamic-relational activation, and as cultural and intercultural learning.

The idea of a multimedia educational theater refers not only to the last moment of representation, but also especially as a resonance of the processes that lead to the representative forms of theatrical reality. "Drama education is a powerful teaching and learning tool with profound positive effects on a student's cognitive, social, emotional, and physical development. (Clark. R., 2013:1)

We did this analysis in the second year of the Drama Club when we decided to perform with "Songs of Milosao." These were non-dramatic texts and poems in Arbëresh. Thirty-seven students adapted the poetic text into dramatic versions, while also makings a 30-minute film with montage and subtitles, all mixed by the students themselves. Meanwhile, we created the costume design and introduced the choir and dances as a bridge connecting it to the ancient theater.

So, we put together the antiquity and modernity in the theater, in a non-dramatic text and we brought it to its original form, according to the most avant-garde forms of theater today, namely that of Desktop Theater, Multimedial Theater, etc. The Drama Club also performed in Italy, near the Arbëresh (Albanian community in southern Italy), where it was very well received by critics. The function of this dramatic laboratory, like G. Bolton states, is to "raise the level of school learning from subject-bound parameters to 'a study of mankind" (Bolton, G., 1998: 177).

So, theater is understood as any possible form of expression, which tends to represent reality in all its various performances, for example, in language (poetry, narratives, music, painting, body language, etc ..), history, the present, the past, the future, in the dream, fantasy, imagination... In this way, theater becomes a transversal pedagogical tool for all languages and disciplines of organizational models of curricular schools. As J. Goodwin states drama is any effective tool for also teaching pronunciation, (discourse, intonation, nonverbal communications, etc. (Goodwin, J., 2001).

\section{Findings}

According to the experience that the students of "Drama club" receive from all this process, it should be emphasized that the complexity of the organization of the show brought also their engagement, as we mentioned above, in an enterprise that required a full collaboration where the idea 
of team-work was present in every step. Putting this show onto stage not only had an artistic and professional aim but also made more present the solidarity of the team which helped to increase their self confidence and the rensponsibility to undertake an assignment and to understand that every enterprise, if we want it to be successful, requires the presence of the others. In this way everyone achieves his or her own personal growth.

In our case, theater is a great value-forming element, which is also raised as an experience of the dramatic laboratory of texts, which usually come into contact only through reading. We are talking here specifically about the dramatic text "Emira", considered the first Albanian drama, structurally shaped with a unique contribution to our drama, which shows various difficulties in decomposition, recognition and reception. The "Emira" drama was precisely represented at the University Theater Festival in June of this year. A fragment of the text "Drama Club" was staged earlier on World Book and Copyright Day, in April of the same year, in honor of the 200th anniversary of the birth of Santori (the first Albanian playwright).

The recognition of the aesthetic and artistic aspects of the theater, as well as the critical and analytical evaluation of this dramatic text in the auditorium, significantly created the possibility of touching the elements and principles of stage art, as well as penetrating the whole of a special theatrical experience which gives a classical text with the difficulty of interpreting in the original, to move to a concrete process of stage realization. The choice of episodes and scenes, adapted to the specific stage possibilities, conditioned by several mise-en-scène lines evidenced in the authorial didactics, contributed to the dramatic temporality of the fictional space of the work. "The written text, in other words is defined from the need it has for contextualization into the stage and shows through all its loyalty with the conditions of the performance, above all with the body of the actor and his ability to embody the discourse inside the space of the scene." (Elan, K., 1980: 208-209).

Thus, during the table process, the students got information about the connection between the history of drama and Albanian theater, starting with the drama "Emira", information on the connection of theater with social movements, on philosophical, aesthetic and psychological concepts of the relevant dramatic time space, the author himself, as well as on anthropological, ethnographic, costume design, lifestyle elements etc. The inclusion of the students in the creative process in the workshop of "The Drama Club" has given them the opportunity to be part of a social interaction and exchange of ideas during the role delivery process, the emotional analysis of the dramatic situations and also the analysis of the characters the students are assigned to play. This process has brought an atmosphere of collaboration between the young actors, which is a substantial element of their relationship within their role, and resulted in a professional and emotional consolidation in their approach to their responsibility to fulfill their project with professionalism.

Creating dramatic spaces, something which the public would perceive through dramatic text, stage space, gestures and metaphorical interior spaces, we considered by obtaining the actanic projection of the dramatic world, i.e the dramatic fable of the work itself.

As described by Lotman and Ibersfeld, (Ibersfeld, An., 2006: 320-321), this space, which was divided into two parts, was reflected in two lines describing the drama, practically in conflict with the two subjects, the dramatic people, (fictions), those who desire and the desired object itself.

It was here that the acting game of Kalina, Emira, Kallonjer and Morian was played, but also the other fictional line of villagers with Cubans, evildoers, complementing the dramatic discourse as a linear continuation of these two paradigms. This highlighted the ideas and philosophy of the Franciscan, which included virtue, faith in God, life, and even though an economic impossibility, love and other spiritual values. "The textual analysis of the show [...] builds a new theory, the "spectacular text" which is the result of the supposed material object "theatrical show" inside the paradigms of the textual semiotics that interacts as an explanatory principle (as well as an analitic-descriptive model) regarding the discursive function of the concrete theatrical phenomenon.( De Marinis, M., 1982:11)

Built as a classic drama, with coral elements as a model of ancient tragedy, as well sas onflict and catastrophe and the causality of the course of action, with regards to the unity of time and place, the text gave us the opportunity of a supporting basic scenography by creating and constructing a green forest at the scenic ends of where we placed costume objects and artifacts from the pastoral life of the era. The aristocratic Aristotelian elements we brought in with the version of "voices of the choir", according to the Brehtian model, which gave the opportunity to expand in their own space the dramatic fable. Seen as a necessity of stage and directorial application, between classical theater, which means the text itself and the most receptive experiences today, we synthesized the role an actor, who through the use of gestures, realized seven dramatic characters: Ferdinand, Carl, Arkansas, Genc, Pascal, January, and Gabriel. This was done by identifying each with objects, expressions, mimicry, gestures, choices that resulted in a very special innovation, which quite well received. In order to have a theater, says Freud, we must first have identification and catharsis, true pleasure, which results from the release of our tension.

"Emira" stood up to the challenge of applying modern theater best. Modern reading theory raises two semantic issues: In what way does the text express meaning (in our case the dramatic one) and what does it mean? Naturally, if we consider that the stage text is the dramatic event itself, 
as a dramatic fact, that the composition is part of the meaning itself, that the form itself in the drama is also significant, we conclude that the laws of dramatic writing, structure as semantic matter, acceptance theory, were inherent and essential in our drama Emira. "The prose has a narrator, while the dramatized text lacks a narrator. Action is left to your hands" (Lethbridge, S., Mildorf, J., 1991: 91-99).

The aspect of lecturing and interpretation in Arbëresh (the dialect of the Albanian community, which is not practiced in Albania), was another difficulty. We believe that the tradition created in the "Drama Club", the reading process, the dynamics of the dramatic event itself, and of course, the consultation in cases of incomprehensibility with the transcribed text, gave us the opportunity to present ourselves with dignity, to perform a service to our classical literature, by interpreting the original, but also to engender great empathy in the public, which had not known this text scenically.

Our attention particularly focused on the possibility of emotional involvement of the student-actor with the dramatic literary text, in recognizing, practicing and pronouncing correctly, the diction of speech, the technique of logical, rhythmic and emotional accent and the role of intonation in communication. By staging "Emira", it was promoting the meeting with a text of dramatic literary genre through dramatic action: we showed a new way to understand and learn in dynamic-relational planes, that of interpersonal, psychological, emotional, and theatrical communication, etc.

\section{Focus Group - Testimonials of members of "The Club of Drama"}

\section{Sonja Llana \\ First Year Students in Master of Science, University of Tirana}

It is hard to define what drama club is because of the many years and generations being part of it has made it seem like the equivalent of a school. Drama, this third literary gender, has its own difficulty in understanding only through reading, since it is projected to be staged. Decoding the dramatic text and dramatic characters starts from working on a table up to the visualization on the stage, and serves not only as a deeper acknowledgment of drama as a genre, but also in Albanian literature on both diachronic and synchronic levels.

The club is a laboratory in discovering new talents, raising them professionally also in the didactic interpretation and diction aspect, which is not just important in the field of literary studies, but also for teaching and other disciplines. Drama aids in the learning process through a different form using a variety of means.
That is why it should be part of the process of learning in all stages of schooling.

Four years ago, when I was accepted in drama club after my audition, I could not even imagine the benefits as a student. The club does not only assist academically, but it also elevates the social spectrum, strengthening and helping relationships between students and group work.

Last year, the drama club succeeded in accomplishing a challenge and a dream. "Emira", Anton Santori's drama, for the club and Kalina's character for me was very challenging for both interpretative forms and getting to know another language, that of the old Albanian preserved by Arbëresh. The drama did not only consist of meeting interpretive criteria, but also costume design and scenography, which we made all by ourselves. Drama club is the best opportunity for a student to delve into the field in which he or she is dedicated to, cultivated in and passionate about.

We have noticed that stimulation, through theatre, serves as a perfect way to combat toxic individualism and existential loneliness (Blatner, A., 2009).

Also, education through theatre associates the autonomy to promote individual choices in a healthy space of a democratic coexistence. The interpretation of the modern and postmodern texts of foreign authors was one of the main purposes of this process.

\section{Xhesika Gjeçi \\ University of Tirana - Faculty of History and Philology}

I realized that acting was one of my passions while studying Albanian Language and Literature in university, which had a Drama Club.

During the first year of drama club, these students dramatized and staged the Arberesh work "Songs of Milosao" by an Arberesh author Jeronim De Rada. This show was successful not only within the University but was also performed on the stage of Metropol Theatre in the center of Tirana. The size of the show as well as the Drama Club itself became significant.

I am proud to share with you that I became a representative of this Drama Club as well as one of the first participants.

I was lucky enough to be part of the interpretations of dramatic texts, remembering the role of Ganxhe in the drama "Rrajt lëvizin" by the Albanian author Ernest Koliqi, as well as in the interpretations of poems which went through the dramatization process.

I would like to mention the creations of Martin Camaj as well as foreign creations like the ones of the great Shakespeare.

I was lucky to learn the process of dramatization through which a literary text, such as prose or poetry, would be converted into a dramatized text using interpretation.

As I have gained a unique didactic and curricular experience and left my mark at the Drama Club, I will 
continue to follow the new generation and the shows produced by this Club.

I would like to mention the wonderful performance of young actors with the staging of Migjeni, (one of the greatest authors of Albanian Literature of the $20^{\text {th }}$ century, due to his complex way of creating a literature that broke the old aesthetic creative patterns by proposing new ways of making literature. This included using free verse in poetry and the writing of short and powerful stories instead of $\log$ epic novels) the evidence of the dramatization process that magically reawakened the work and figure of this contemporary author of our country.

As I teach students Albanian Language and Literature, I try to inspire them to gain an appreciation for dramatic text. In my opinion, it is beneficial for the students to make dramatization a basic part of the lesson and one of the main methodologies in the learning process because drama builds confidence in even the most timid students. It helps them focus, and students are encouraged to listen to others' ideas and thoughts.

Drama helps to develop language and communication skills because when children have to learn the language of the role they play, their vocabulary expands.

They are encouraged to express themselves both orally and through facial expressions. Understanding body language is the key to make them better communicators. Above all, drama develops creativity. Creative people can see things in new ways and from different angles.

The skills I have gained at the drama club are transmitted to my students in order to continue to provide the society with talented individuals.

\section{Egli Bogdani}

\section{Student of Albanian Linguistics and Literature Faculty of History and Philology University of Tirana}

Being part of Drama Club is not only a great opportunity for us, but it also allows for professional growth. It is an excellent experience in the field of acting because it expands the concepts of the world of acting and clarifies the concept of theatre. The Drama Club is an innovation in the Albanian universities and the prestige of this club is growing from year to year. The most interested are students who study Albanian philology, because in this group they see a series of sourcing benefits in their professional development. Many students really like to participate in these work groups, because during these types of activities the challenges are so important and at the same time, they can learn many new things.

My first experience in this group was in 2017 (first academic year as a BA student), and continues to this day. Thus, my journey during these years as part of the staff of actors in the Drama Club has been helpful in my professional growth as a devoted student of Albanian literature and culture. By this point I meant the way of analyzing a literary work or a play, and in the changes that a prosaic text undergoes when it turns into dramatic text. Also through this experience together with other colleagues, we have learned how the theatrical world works by experiencing every emotion that a well-formed actor would experience. We must admit that the Drama Club has been set up by a non-professional theatrical troupe, and the main components of this club are the students that exude inexhaustible curiosity, and a desire to learn something different.

It has already become a tradition that on April $23^{\text {rd }}$ of each year, on National Book Day, in addition to other activities, such as literary conferences or new book promotions, a play is given by the Drama Club. The Drama Club comes up with a new author at the event, featuring a host of literary works by that author, including poetry and prosaic texts. The first author that I presented together with my colleagues was Millosh Gjergj Nikolla. In the script we included poems of the author and short prose as well. During the theatrical performance I realized how a prosaic text was dramatized, and how this drama interacted with other components like music, lights, costumes, and movements (Mise-en-scène). Thus my first experience in this play helped me to understand the theatrical, dramatic and literary artistic dimension in general.

Another important experience was the staging of the classic drama "Emira" by the Arbëresh author Francesc Anton Santori. This play was performed on the stage of the Faculty of History and Philology, as well as on the stage of the Experimental Theater of Tirana, one of the most important theaters in Albania. Performing this drama was more challenging than "Migjeni". The first challenge was language. Since F.A.Santori was a classical author, it was necessary to interpret the drama in the autochthonous Arbëresh language. Thus, in a record time we learned the Arbëresh language, a dialect which is very different from the standard Albanian language. This drama was doubly valuable for us because at the same time we learned more about the Arbëresh culture, and in particular about the Arbëresh drama/plays, but we also learned how to speak Arbëresh. Here I would like to highlight the values of this precious variant of the Albanian language that is inherited generation after generation from the Arbëresh community.

Thus, during the table process the students were informed regarding the relationship between history and the Albanian theatre that starts with "Emira". This information was related with the theatre and the social movements, over philosophical, aesthetic and psychological concepts regarding the dramatic space, regarding the author of the dramatic piece, anthropological, ethnographic, the way of living etc. In this way the students became more responsible for the process of learning, as their experience and recreation. (Miller-First, M., Ballard, K., 2017: 25).

The drama "Emira" was the first impetus from which arose my interest and the idea to go deeper into literature, culture, and the Arbëresh drama studies. Participating in 
the Drama Club was a great opportunity to get more knowledge about the southern Italian population, to seek more information from different points of view, such as history as well as culture, as well as clarifying why this community is known as Piana degli Albanesi, and finally understanding which are the branches that connect this community with Albania. After my studies at the University of Saarland in Germany and my research on Italian romantic literature, I decided to develop my diploma thesis on the Arbëresh drama, specifically for the plays of Giuseppe Schirò Di Maggio (Zef Skiro Di Maxho), a well-known contemporary Arbëresh writer.

In conclusion, the aim of the Drama Club is to convey literary and cultural awareness by encouraging the Albanian world (inside and outside the borders) to show interest in Albanian literature of all periods, and not letting this collective wealth to be reduced to the ash heaps of history.

\section{Mario Loçka \\ Ex member of the Drama Club - University of Tirana Lecturer at "Charles University" in Prague}

Time and again I am constantly captivated by thrilling theatrical recollections of my valuable experience at the Drama Club. I became part of this university establishment during my first year of studies, through a very inspiring and entertaining audition. After the speech that I had chosen, the mentor complimented my breathing technique and the voice play. It gave me an immense confidence boost. Prior to that, I had only minor experiences in school plays, which pushed me to aim for a spot in the selected few of the Drama Club ranks.

I had the chance to be part of different presentations, but I would like to point out two performances that I cherish the most: staging the dramatic piece "Rrajët Lëvizin" by Ernest Koliqi, and a partial powerful monologue from "Oh!" by Anton Pashku. These pieces, written in Albanian, were dissected to the core by our mentor so that we, the actors, could get the true essence and the substance that was hidden within the characters. Fluently intoning and personifying the dialogues was never enough, since the purest form of correctly interpreting was to understand the emotion and the logic behind the words.

We conducted everything with true professionalism, respecting the laws of the theatre and seriously working on having a perfect completed product. I was always sure at the time that with the right spotlight and resources, Drama Club could present projects worthy of worldwide stages.

The parts I played also helped me grow as an actor. During my experience at the Drama Club I had the chance to portray a wide variety of situations, elucidating archaic accents, and physical transformation because of sizeable age gaps, mentally challenged characters, etc. From the costume designs to the makeup and the scenography, everything was constructed out of passion and commitment of young talented actors and the trailblazer professors, who created this theatrical playground. The never-ending applause and incredible feedback were always a very pleasant reward for all the hard work.

It has been almost three years since my last performance at the Drama Club.

Now I am working as a Lecturer at "Charles University" in Prague, teaching foreign students the Albanian language and Folklore. I would also consider teaching a special kind of performance that lets me be in character for my small personal audience. All of this is possible thanks to the tempering that the Drama Club helped me construct. The executed performances and the strict theatre discipline that I was able to absorb, have elevated my path to higher goals in my career. The Drama Club journey is an important experience that I will absolutely continue to pursue.

\section{Omer Fuçia \\ Sophmore Year, Bachelor Degree, Albanian Language and Literature Major}

I joined the Drama Club practicing any from the theoretical knowledge I had. While I was in the library, I grabbed a book and learned the basics of theatrical language, interpreted, applauded and felt the magic of the theater. The drama called "Emira" was my first challenge that I was faced with. "Emira" is a drama written in old Arabic by Anton Santori. We did the decomposition of the dramatic characters, the decomposition of the conflicts and we tried to get into the author's feelings while also retaining his style. Rehearsals at the table, rehearsals in motion, costume design, scenography, mimics, movements, and much more were analyzed to the greatest extent possible. It was the first time that the dramatic characters of the "Emira" drama would step on the stage interpreting in Arabic language. That's going to stay in the theater's legacy. Today, I am thankful for the experiences I gained at the Drama Club because I can now participate in a film audition from where I was accepted. The Drama Club has provided me with many professional experiences that will facilitate my work in the future.

\section{Conclusions}

Theater in school entails a: "concrete interdisciplinary approach", which activates the processes of symbolic learning and strengthens and develops an interactive variety of individual skills and abilities in the service of the curriculum. Apart from the theater, as a textual explanatory approach, useful knowledge of all disciplines, as poetry, history, literature itself, physics, philosophy, mathematics can become theatrical signs and meanings.

Besides this, the theater coexists with other art forms and other cross-curricular topics, such as film, documentary, and reportage, with technical processes such as editing, 
subtitling, and mixing by making the stage communication interactive and attractive between the student or pupil and the audience. It is this coexistence that emerges as a typical social, cultural experience. In this sense, the educational value of theater goes beyond the same forms of communication that produce it.

In conclusion, we can say that not only does the school make theater, but that the theater makes school as well.

\section{REFERENCES}

[1] Clark, R., (2013). Drama Techniques, Exeter: IPC.

[2] De Marinis, M., (1982). Semiotica del teatro. Analisi testuale dello spettacolo, Milano: Bompiani.

[3] Elan, K., (1980). The Semiotics of Theatre and Drama, London and New York: Routledge.

[4] Louis, E. Catron., (1993). The Elements of Playwriting, New York: Macmillan.

[5] Karamitri, E., Koçi, P., Murthi, M., Pepa, V., (2001). Letërsia në shkollë, Tiranë:AEDP

[6] Hasani, D., (2015). Vepra e dramatizuar midis Letërsisë dhe Artit. Tiranë: Naimi.

[7] Ibersfeld, A., (2006). "Koha dhe hapësira teatrore" Hysaj, F., Teatrologji, dramaturgji, regji dhe aktrim; antologji tekstesh. Prishtinë: Sythi.

[8] Kowzan, T., (1975). Litterature et Spectacle, Paris: Mouton.

[9] Pavis, P., (1982). Essays in the Semiology of Theatre. Presses Universitaires de Lille: Performing Arts Journal Publications.

[10] Lethbridge, S., and Mildorf, J., (2004). An introductory course for students of literary studies in English. Developed at the English Departments of the Universities of Tübingen, Stuttgart and Freiburg: Version 12/3.

[11] Gravey,V., Lorenzoni,I., Seyfang G., Hargreaves,T.,(2017).
Theoretical Theatre: Harnessing the Power of Comedy to Teach Social Science Theory, Journal of Contemporary European Research Volume 13, Issue 3.

[12] Bundy, P., Ewing, R. \& Fleming, J. (2013). Drama and the Audience: Transformative Encounters in TheatreSpace. In M. Anderson \& J. Dunn, eds. How Drama Activates Learning. London: Bloomsbury.

[13] Freeman, J., (2009). Blood, Sweat and Theory: Research through Practice in Performance Music + Performing Arts. Faringdon: Libri. [Google Scholar].

[14] Goodwin, J., (2001). Teaching, pronunciation in M.Celce Murcia.Teaching English as a second or Foreign language, $3^{\text {rd., }}$ ed., Heinle \& Heinle.

[15] Elan, K., (1988). The Semiotics of Theatre and Drama, London, Methuen \& Co, 1980, trad. it. di F. Cioni., Bologna: Il Mulino.

[16] SCHECHNER, R., (1994). Environmental Theatre, New York-London: Applause Books.

[17] Heyward, P., (2010). Emotional Engagement Through Drama: Strategies to Assist Learning through Role-Play, International Journal of Teaching and Learning in Higher Education, Vol 22, Nr 2, http://www.isetl.org/ijtlhe/

[18] Heyward, P., (2010). Emotional Engagement Through Drama. Strategies to Assist Learning through Role-Play, International Journal of Teaching and Learning in Higher Education, Vol 22, Nr 2, http://www.isetl.org/ijtlhe/

[19] Bolton, G., (1998). Acting in Classroom Drama: a critical analysis. Stoke on Trent: University of Central England, Faculty of Education.

[20] Landon E. B., (2001). The Value of Critical Perspectives in Teacher Education, Journal of Teacher Education, 52 (2).

[21] Freire, P., (1968). Pedagogy of the Oppressed. New York: Seabury.

[22] Miller-First, M., Ballard, K., (2017). Constructivist teaching patterns and student interactions. Internet Learning (6), 1.

[23] Blatner, A., (2009). Role Playing in Education. https://www.blatner.com/adam/pdntbk/riplayedu.html 